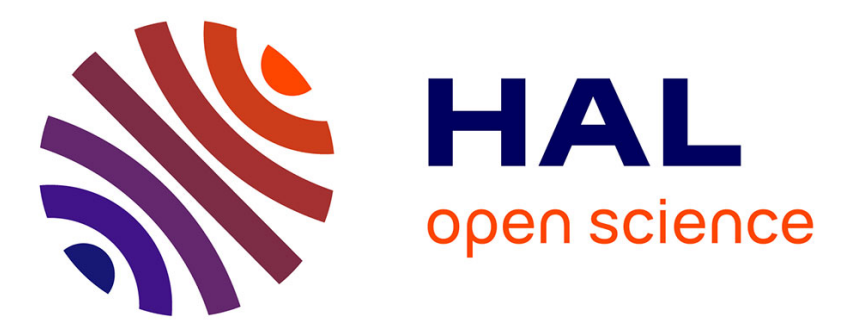

\title{
PUMP-CTD-System for trace metal sampling with a high vertical resolution. A test in the Gotland Basin, Baltic Sea
}

Emilie Strady, Christa Pohl, Evgeniy Yakushev, Siegfried Krüger, Ursula Hennings

\section{To cite this version:}

Emilie Strady, Christa Pohl, Evgeniy Yakushev, Siegfried Krüger, Ursula Hennings. PUMP-CTDSystem for trace metal sampling with a high vertical resolution. A test in the Gotland Basin, Baltic Sea. Chemosphere, 2008, 70 (7), pp.1309-1319. 10.1016/j.chemosphere.2007.07.051 . hal-02357372

\section{HAL Id: hal-02357372 https://hal.science/hal-02357372}

Submitted on 14 Nov 2019

HAL is a multi-disciplinary open access archive for the deposit and dissemination of scientific research documents, whether they are published or not. The documents may come from teaching and research institutions in France or abroad, or from public or private research centers.
L'archive ouverte pluridisciplinaire HAL, est destinée au dépôt et à la diffusion de documents scientifiques de niveau recherche, publiés ou non, émanant des établissements d'enseignement et de recherche français ou étrangers, des laboratoires publics ou privés. 


\title{
PUMP-CTD-System for trace metal sampling with a high vertical resolution. A test in the Gotland Basin, Baltic Sea
}

\author{
Emilie Strady ${ }^{a, b}$, Christa Pohl a,*, Evgeniy V. Yakushev ${ }^{\text {a,c }}$, Siegfried Krü ger ${ }^{a}$, \\ Ursula Hennings a \\ ${ }^{a}$ Baltic Sea Research Institute, IOW, Seestrasse 15, D-18119 Warnemu"nde, Germany \\ ${ }^{\mathrm{b}}$ University Bordeaux 1, UMR CNRS 5805 EPOC, Avenue des Faculte's, 33405 Talence, France \\ ${ }^{\mathrm{c}}$ Southern Branch of Shirshov Institute of Oceanology, (SB RAS), Krasnodarskii Kray 353467, Gelendzhik 7, Russia
}

Received 23 March 2007; received in revised form 16 July 2007; accepted 20 July 2007

Available online 4 September 2007

\begin{abstract}
It is a great challenge to sample seawater across interfaces, for example the halocline or the redoxcline, to investigate trace metal distribution. With the use of 101 sampling bottles mounted to a wire or a CTD-Rosette it is possible to obtain a maximum vertical resolution of $5 \mathrm{~m}$. For the detection of small vertical structures in the vertical distribution of trace metals across the redoxcline, the CTDBottle-Rosette is not sufficient. Therefore, a PUMP-CTD-System was developed, which enables water sampling with high resolution (1 $\mathrm{m}$ maximum) along a vertical profile. To investigate the suitability and possible contamination sources of this device two experiments were carried out in the Gotland Basin. The first experiment consisted of two separate profiles. The first profile was obtained with the CTD-Bottle-Rosette and the second with the PUMP-CTD-System. Both were taken from the bottom to the surface water layer. The second experiment was a combined profile obtained from the surface to the bottom with the PUMP-CTD-System attached to the CTD-Bottle-Rosette. Concentrations of dissolved $\mathrm{Pb}, \mathrm{Cd}, \mathrm{Cu}, \mathrm{Zn}, \mathrm{Fe}, \mathrm{Mn}, \mathrm{Co}$ and Ni from the "Niskin Bottles" and from the PUMP were measured and compared for each investigation. We demonstrate that it is useful to perform vertical sampling from lower to higher concentrations, e.g. surface to bottom in this environment, and that a longer flushing is required for sampling seawater in the anoxic bottom water. A comparison of the two systems for oxygen and hydrogen sulphide measurements showed an improvement of the precision and the quality of the sampling when using the PUMP. Thus, metal speciation at the oxic-anoxic gradient zone and on a high vertical resolution will be accessible. As concentrations of dissolved $\mathrm{Pb}, \mathrm{Cd}, \mathrm{Cu}, \mathrm{Zn}, \mathrm{Co}, \mathrm{Ni}, \mathrm{Fe}$ and $\mathrm{Mn}$ in seawater sampled with both devices were in the same range, we conclude that the PUMP-CTD-System is well suited to sample seawater for trace metal analyses.
\end{abstract}

Keywords: Seawater sampling device; Trace elements; Anoxia; High resolution sampling; Quality assurance

\section{Introduction}

Sampling seawater to study trace metal distribution and speciation across redox interfaces is a great challenge: the sampling must be without contamination, without losses of water, should achieve a high vertical resolution, and

\footnotetext{
${ }^{*}$ Corresponding author. Tel.: +49 3815197321 ; fax: +49 3815197302.

E-mail address: christa.pohl@io-warnemuende.de(C. Pohl).
}

has to avoid changes in the redox state. Thereby, the sampling device requires being adapted to the physical characteristics of the environment and to the level of trace metal concentrations in the water. Open ocean, concentrations of trace metals are relatively low (Pohl et al., 1993, 2007). Therefore, the sampling systems commonly used are precleaned (coated) Go-Flo bottles (General Oceanics) mounted on CTD/Rosette (San udo-Wilhelmy et al., 2002), with sometimes Teflon-coated CTD/Rosette frame (LO” scher, 1999). In shelf, coastal and estuarine areas, like 
the Baltic, concentrations of trace metals are higher $(\sim$ factor 4 for $\mathrm{Cd}$, factor 3 for $\mathrm{Pb}, \sim$ factor 10 for $\mathrm{Cu}, \sim$ factor 10-50 for $\mathrm{Zn}$ and $\sim$ factor 500 for $\mathrm{Fe}, \mathrm{Mn}$ ) (Pohl, unpub-

lished data) and so the seawater can be sampled with Niskin bottles, polypropylene-made bottles (Waeles et al., 2004), or Teflon PUMP and tubing (Rondeau et al., 2005). In lakes, concentrations vary according to physical characteristics of the environment. Thus, the sampling device should require a better vertical resolution and should avoid contamination. In that case, cleaned pumping systems in combination with a peristaltic PUMP are used (Brezonik et al., 2003).

Investigating trace metals in the Baltic, especially in the Gotland Basin area, has a long tradition (Kremling, 1973; Brü gmann, 1974; Schneider et al., 2000; Pohl and Hennings, 2005; Pohl et al., 2006). The water column is characterized by a permanent halocline in the $\sim 75 \mathrm{~m}$ depth horizon and a redoxcline ranging between $200 \mathrm{~m}$ and 150 $m$ depth during stagnant conditions. The Gotland Basin is the largest $\left(13860 \mathrm{~km}^{2} / 90 \mathrm{~m}\right.$ isobath $)$ deep area (maximum depth $248 \mathrm{~m}$ ) in the Baltic Sea. The changing redox conditions observed inter annually in the water column induces modifications in trace metal speciation and distribution (Kremling, 1983; Brü gmann, 1988; Pohl et al., 2004, 2006; Pohl and Hennings, 2005). Typical concentrations of trace metals observed in this area are comprised between $0.01 \mathrm{nmol} / \mathrm{kg}$ and $0.016 \mathrm{nmol} / \mathrm{kg}$ for $\mathrm{Pb}$; $0.02 \mathrm{nmol} / \mathrm{kg}$ and $0.19 \mathrm{nmol} / \mathrm{kg}$ for $\mathrm{Cd} ; 3 \mathrm{nmol} / \mathrm{kg}$ and 25 $\mathrm{nmol} / \mathrm{kg}$ for $\mathrm{Zn} ; 1 \mathrm{nmol} / \mathrm{kg}$ and $10 \mathrm{nmol} / \mathrm{kg}$ for $\mathrm{Cu} ; 10$ $\mathrm{nmol} / \mathrm{kg}$ and $21000 \mathrm{nmol} / \mathrm{kg}$ for $\mathrm{Mn}$ (Pohl and Hennings, 1999, 2005; Neretin et al., 2003).

Sampling seawater in such particular environment entails a specific and adapted device. Until now, seawater for trace metal analyses in the Baltic Sea was collected by 101 Close-Open-Close bottles (General Oceanics) and Niskin bottles mounted on a CTD-Rosette, which enables a maximum depth resolution of $5 \mathrm{~m}$. But for the detection of small vertical structures in the distribution of trace metals and also nutrients through the redoxcline, the CTDRosette was not sufficient. Therefore, a pumping system was modified and optimised by the IOW (Institut fü $r$ die Ostseeforschung, Warnemu“ nde) and the MPI (Max Plank Institute for Microbiology, Bremen), which enables water sampling with high resolution $(1 \mathrm{~m})$ along a vertical profile.

The aim of this study was to determine the suitability of the PUMP-CTD-System, for dissolved trace metal measurements and distribution $(\mathrm{Pb}, \mathrm{Cd}, \mathrm{Zn}, \mathrm{Cu}, \mathrm{Co}, \mathrm{Fe}, \mathrm{Mn}$ and $\mathrm{Ni}$ ) across interfaces in the Gotland Deep. As a consequence we compared the two sampling methods, samples taken from bottles attached to a "CTD-Bottle-Rosette", and from the PUMP-CTD-System, and compared different approaches of sampling by examining how they can affect the measured concentrations and to rule out contamination. Therefore, we investigated the potential contamination of the water by the PUMP-CTD-System itself and suggest further improvements of the system.
2. Materials and methods

\subsection{PUMP-CTD-system}

The IOW/MPI-PUMP-CTD-System is an integrated measurement device. It was developed in collaboration between IOW and the MPI Bremen nutrient group, in 2001 following the ideas of Friedrich et al. (1988), from MBARI (Monterey Bay Aquarium Research Institute) California. The system enables profiling CTD-, $\mathrm{O}_{2-}$, Fluorescence-, Turbidity, and ADCP-measurements in combination with continuous water sampling over a water column of $350 \mathrm{~m}$ depth. The complete system is shown in Fig. 1. It consists of the submersible CTD-, Rosette- (with Teflon-coated Niskin bottles), ADCP- and PUMP probe unit, an underwater camera, a nylon PUMP hose, a computer controlled winch with an electrical and fluid slip-ring system, a special insulating high power electrical supply unit, the CTD-deck-unit, a digital flow meter for the water stream, and three PCs for CTD-, Rosette-, ADCP-, and winch control (Krueger, 2004; personal communication). During sampling, the pumped water flows through the nylon hose directly to the laboratory.

The flow rate of the PUMP-CTD-System is dependent on the individual PUMP and the complete cable- (hose-) length on board. Immediately after a setup for an expedition it is tested by an "ink test", while the flow rate is measured and displayed permanently ( $1 \mathrm{ml}$ of ink is pushed into the inlet and than monitored at the outlet, stopping than the travelling time). The "ink test" is very sharp and accurate on $\pm 1 \mathrm{~s}$. It shows the very low smear of the whole system. After the "ink test" an individual nomogram (not shown here) for the application on board is calculated. This nomogram shows the travelling time over the measured flow rate. During our expeditions the actual flow rate was $2.875 \pm 0.025 \mathrm{l} / \mathrm{min}$ at $355 \mathrm{~m}$ of over all hose length corresponding with a travelling time of 3:51-3:57 min. For high resolution sampling the probe can be lowered with a constant speed of $0.1 \mathrm{~m} / \mathrm{s}$. For the CTD in the PUMPCTD-System a SBE911+ from SEABIRD-Elec- tronics USA is used. In this system the DIGIQUARZ(R) pressure sensor is extra isolated from thermal changes and additionally corrected by an extra inner temperature sensor (Ref.: www.seabird.com and www.paroscientific. com).

To prevent contamination during sampling, parts of the system directly in contact with water have been adapted for trace metal studies. Despite of this, the PUMP inlet of the system was still identified as a possible source of contamination (Fig. 2) after the two cruises in 2005 (see Section 4 ).

Comparing the two systems, the PUMP-CTD-System would have a few vantages according to our multi-purpose for example, the resolution is $1 \mathrm{~m}$ for the PUMP against 5 $\mathrm{m}$ for the Rosette and the sample volume is unlimited. The vertical speed of the rosette $(0.1 \mathrm{~m} / \mathrm{s}$ for both systems can be adapted at constant level for the PUMP. At last, the 


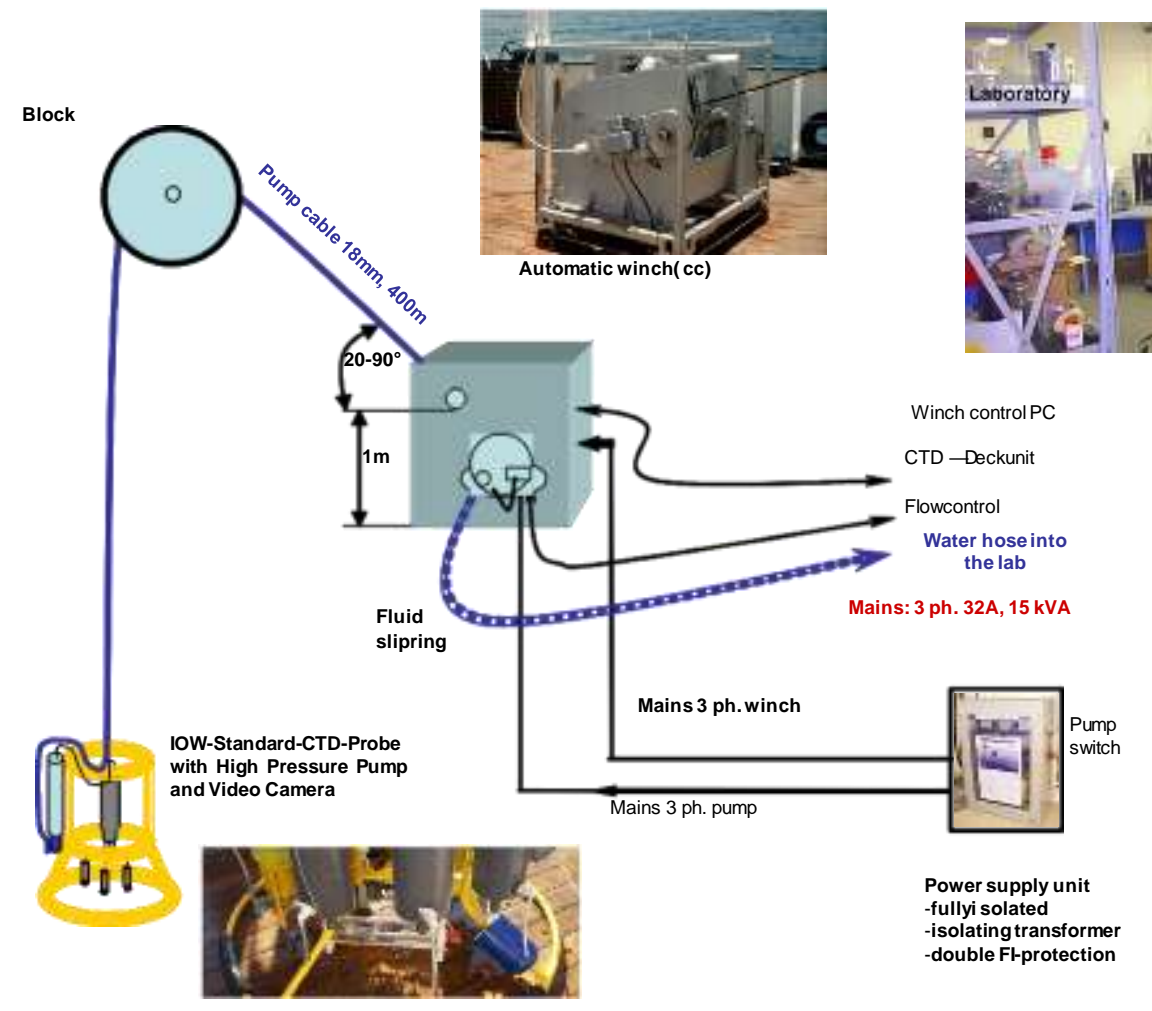

Krueger, 2004

Fig. 1. IOW/MPI-Pump-CTD-System (Krueger, 2004).

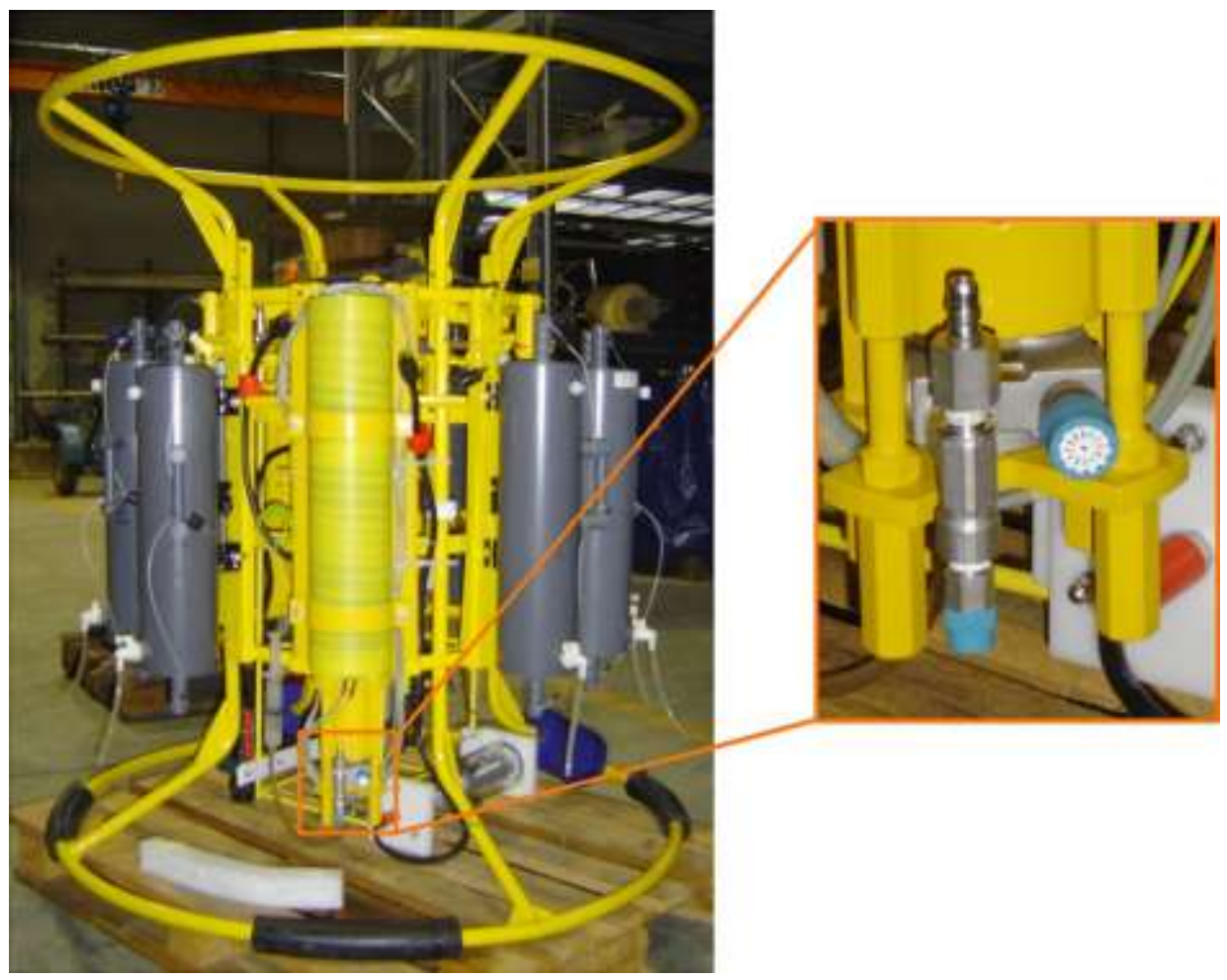

Fig. 2. Pump-CTD-System attached to CTD-bottle-Rosette, with Free-FLO bottles and submersible water camera. View on the pump inlet, made of stainless steel (10 cm long).

sample treatment on board is different: with the PUMP, the water is coming within 4 min directly to the laboratory while with the "classic bottles", the water is stocked in the bottle and can stratify until the treatment on board. 


\subsection{Collection of samples}

Samples were collected in the Gotland Deep (248 m), at the station IOW $271\left(57^{\circ} 18,30^{\prime} \mathrm{N} ; 20^{\circ} 04,60^{\prime} \mathrm{E}\right)$ (Fig. 3). For our investigations, two cruises were carried out, in July and October 2005. In July, sampling was performed onboard of " $R V$ Professor Albrecht Penck" by two separated and independent profiles sampled from the bottom to the surface. Samples for the first profile were taken with the CTD-Bottle-Rosette, which is routinely used for monitoring purposes since 12 years. Samples for the second profile were taken using the PUMP-CTD-System $12 \mathrm{~h}$ later. In October, sampling was carried out onboard 'FS Alkor', using a combined profile from the surface to the bottom with measurements obtained from both systems (Fig. 2). Samples to compare oxygen and hydrogen sulphide concentration in seawater sampled with the two devices were taken in February 2006 onboard "Maria S. Merian". The high resoluted combined profile was carried out across the redox interface between $110 \mathrm{~m}$ and $120 \mathrm{~m}$ depth. During the three cruises, water samples were collected for each depth studied from the PUMP and from the 101 Niskin bottles.

\subsection{Samples treatment onboard}

Water samples were pre-treated in a clean bench to prevent contamination, following the same procedure for both cruises. Five hundred milliliters of seawater was pressure filtrated with argon through $0.41 \mathrm{~m}$ pre-cleaned Teflon Nuclepore filters, acidified with $1 \mathrm{~cm}^{3}$ of concentrated suprapur $\mathrm{HNO}_{3}$ and stored in $500 \mathrm{~cm}^{3}$ "Low Density" (LD) Polyethylen bottles. The bottles were then wrapped in Polyethylen bags and stored in plastic boxes until analyses in the laboratory (Grasshoff et al., 1999). Filtration equipment and LDPE bottles were cleaned according to the methods of Patterson and Settle (1976) prior to use.

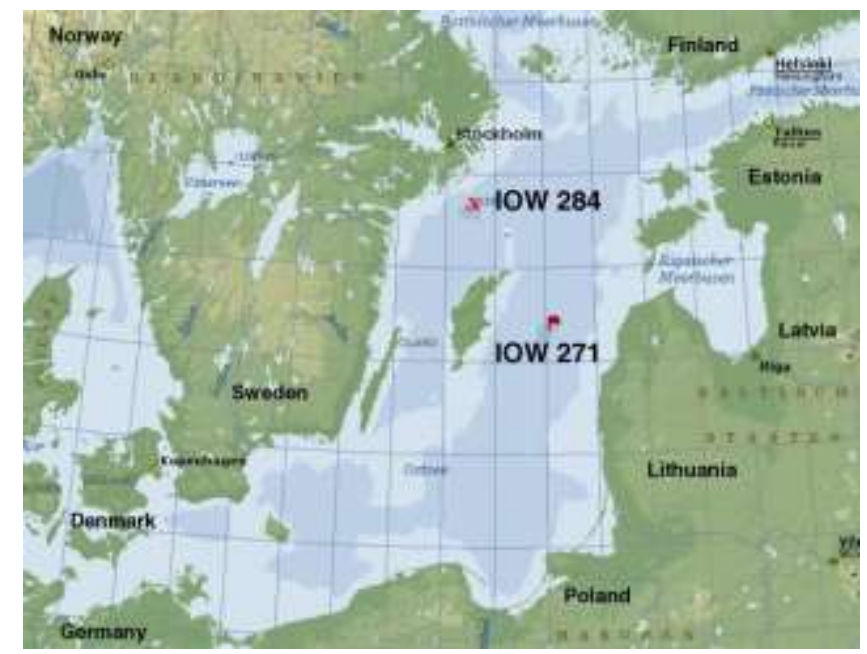

Fig. 3. Location of the station IOW 271 in the Gotland Basin and station IOW 284 in the Landsort Deep, Baltic Sea.

\subsection{Laboratory analysis}

Laboratory analysis were carried out in the home laboratory under clean room conditions and with clean air benches (class 100, US Federal-Standard 209b). Analytical materials used were also cleaned very carefully as recommended by Grasshoff et al. (1999).

To eliminate the salt-matrix, and to reach the working concentration range of our AAS instrument, analysis of dissolved trace metals $\mathrm{Pb}, \mathrm{Cd}, \mathrm{Zn}, \mathrm{Cu}, \mathrm{Co}, \mathrm{Fe}$ and $\mathrm{Ni}$ were performed using an adapted dithiocarbamate extraction and enrichment method from Danielsson et al. (1978) and Grasshoff et al. (1999). The final acid extracts were analysed by "Graphit Furnace Atomic Absorption" (GFAAS) using a Perkin Elmer AA spectrophotometer ZL 4100 and a Perkin Elmer Analyst 800. The detection limits of the method, calculated as three times the standard deviation of the blank are $0.009 \mathrm{nmol} / \mathrm{kg}$ for $\mathrm{Cd}, 0.01 \mathrm{nmol} / \mathrm{kg}$ for $\mathrm{Pb}, 0.13 \mathrm{nmol} / \mathrm{kg}$ for $\mathrm{Cu}$ and $0.15 \mathrm{nmol} / \mathrm{kg}$ for $\mathrm{Zn}$.

To determine dissolved manganese, we used the method based on the extraction of Mn-oxinate in chloroform as described by Grasshoff et al. (1999). For higher Mn concentrations, seawater was analysed directly by GF-AAS. A matrix modifier solution of $10 \%$ palladium nitrate and $1 \%$ magnesium nitrate was applied to reduce interferences from the remaining salt-matrix.

To assure the precision and the quality of analysis, certified reference material (CRM) NASS-5 (North Atlantic Seawater Standard) and CASS-3 (Coastal Atlantic Seawater Standard) from the National Research Council Canada were used as shown in Table 2 and chapter 4.3. Our laboratory takes part regularly and successfully in the QUASIMEME studies for quality assurance. Data for temperature and salinity were obtained from the CTD. Oxygen and hydrogen sulphide were analysed directly onboard according to the method described by Grasshoff et al. (1999).

\section{Results}

To compare both sampling methods, metal concentrations in the seawater samples are presented against depth for each element. In addition, standard deviations from 2 to 4 recurrences including the extraction- and enrichment pre-treatment and measurements at the instrument have been calculated and presented for each sample.

\section{Separated profiles, from bottom to surface (July 2005)}

\subsection{1. $\mathrm{Pb}, \mathrm{Zn}, \mathrm{Cu}, \mathrm{Cd}$}

$\mathrm{Pb}, \mathrm{Zn}, \mathrm{Cu}$, and $\mathrm{Cd}$ concentrations of Baltic seawater measured over depth together with temperature, salinity, dissolved oxygen and hydrogen sulphide are shown in Fig. 4. Lead concentrations measured using the PUMP- CTDSystem are higher than the concentrations measured using the CTD-Bottle-Rosette in the oxic water, and lower in the anoxic part of the water column. For cadmium, the concentrations measured with the two systems are different. 

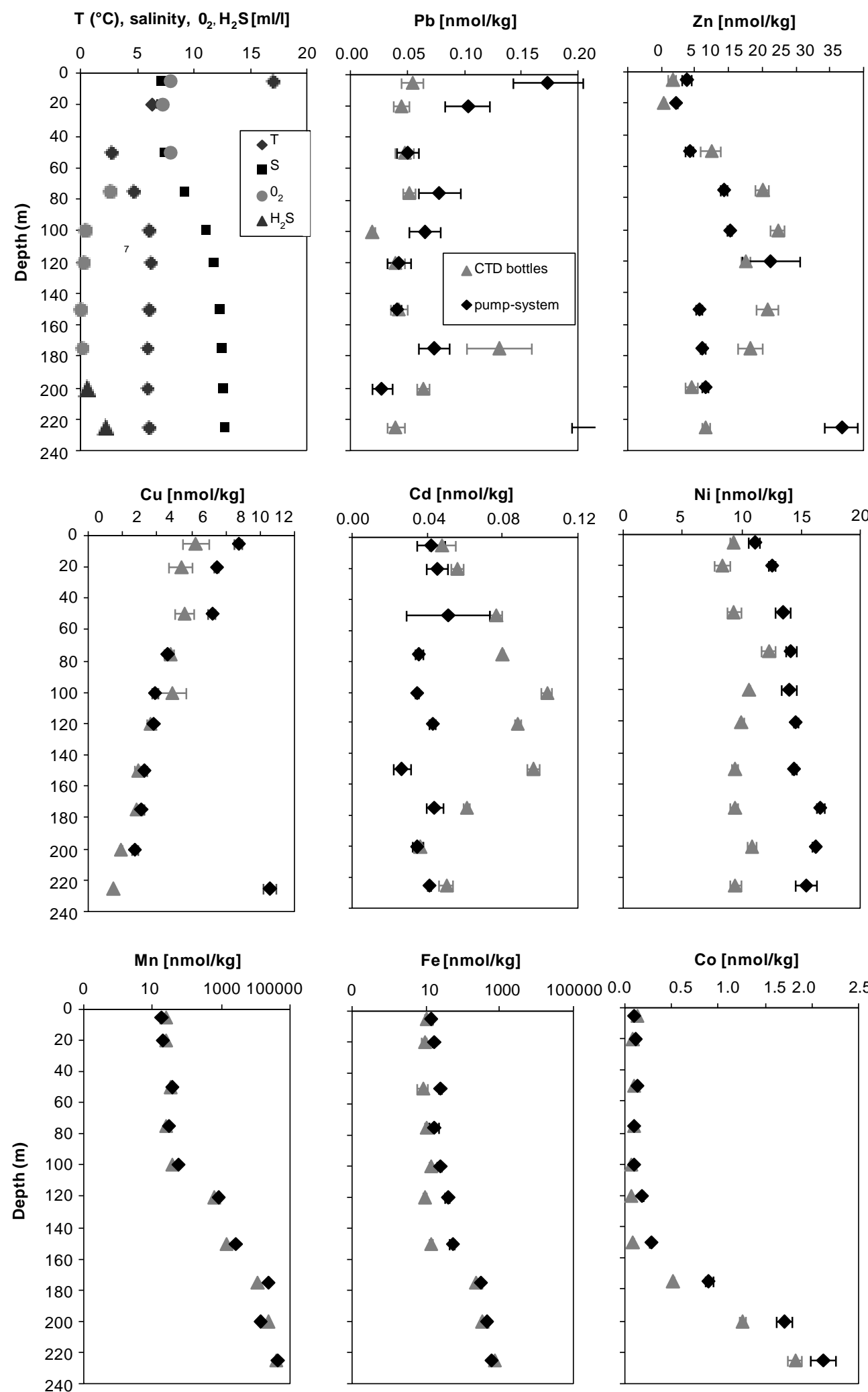

Fig. 4. Separated profiles, bottom to surface from July 2005: (a) profile of $T$ (temperature, ${ }^{\circ} \mathrm{C}$ ), $S$ (salinity), dissolved oxygen and hydrogen sulphide (ml/l) over depth and (b)-(i) profiles of dissolved $\mathrm{Pb}, \mathrm{Zn}, \mathrm{Cu}, \mathrm{Cd}, \mathrm{Ni}, \mathrm{Mn}, \mathrm{Fe}$ and $\mathrm{Co}$ (nmol/kg) sampled from the bottles and the Pump-CTD-System over depth.

From the halocline to the redoxcline, concentrations measured from the PUMP-System are two times lower, whereas in the surface and deep layer they are approximately the same. Zinc concentrations for both profiles 
increase with depth in the oxic water and then decrease in the anoxic water. Nevertheless, concentrations in the PUMP-CTD-System samples are sometimes higher, sometimes lower than in the bottle samples, according to no particular redox behaviour. Copper concentrations are similar for both methods used, except above the halocline where concentrations in the PUMP-CTD-System are higher. $\mathrm{Pb}$, $\mathrm{Zn}$ and $\mathrm{Cu}$ profiles obtained with the PUMP-CTDSystem present nearly the same distribution as the CTDBottle-Rosette profiles, while the cadmium distribution differs from each other. Significant contamination of the water is only observed for the deepest sample, for $\mathrm{Pb}, \mathrm{Zn}$, and $\mathrm{Cu}$ (PUMP-CTD-System), which is possible due to a bottom contact of the whole "PUMP-CTD-System", followed by enrichment and sampling of suspended matter in the near bottom layer.

\subsection{2. $\mathrm{Mn}, \mathrm{Fe}, \mathrm{Co}$}

Manganese, iron and cobalt profiles (Fig. 4) present the same distributions with both systems. In the oxic layer, measured dissolved metal concentrations are very low and in the same range. They then increase with decreasing dissolved oxygen concentrations. In this anoxic body layer, seawater sampled with the PUMP-CTD-System shows slightly higher values of metals, except for $\mathrm{Fe}$ at $225 \mathrm{~m}$ depth and for $\mathrm{Mn}$ at $200 \mathrm{~m}$ depth.

\subsection{3. $N i$}

Distribution of nickel sampled with the two systems is given in Fig. 4. Profiles show higher concentrations when using the PUMP-CTD-System, but the distributions are generally identical.

\subsection{Combined profile, from surface to bottom (October} 2005)

\subsection{1. $\mathrm{Pb}, \mathrm{Zn}, \mathrm{Cu}, \mathrm{Cd}$}

$\mathrm{Pb}, \mathrm{Zn}, \mathrm{Cu}$, and $\mathrm{Cd}$ concentrations of Baltic seawater measured over depth and also temperature, salinity, dissolved oxygen and hydrogen sulphide are shown in Fig. 5. Lead concentrations are close to the detection limit of the analytical method, and induce the large variability of the standard deviation observed. Nevertheless, concentrations of both methods are in the same range except for two depths. At $5 \mathrm{~m}$ the concentration of this metal in seawater sampled by the bottles is two times higher and at $140 \mathrm{~m}$ depth the concentration of $\mathrm{Pb}$ sampled with the PUMP is six times higher. For cadmium, concentrations are similar in the anoxic water, except at $100 \mathrm{~m}$ depth where the concentration in the pumped water was $50 \%$ lower. In the oxygenated layer, concentrations measured from the PUMP-CTD-System are two times higher at 50 $\mathrm{m}$ and almost five times higher at $5 \mathrm{~m}$ depth. For this last position, contaminations during onboard handling can be assumed. Zinc concentrations measured in seawater sampled from the PUMP-CTD-System are higher than concentrations from CTD-Bottle-Rosette in the oxygen- ated layer and lower in the depleted water. At $130 \mathrm{~m}$ depth, the concentration of $\mathrm{Zn}$ in seawater sampled from the PUMP is lower, which results in a different distribution. The use of both systems produces similar depth distributions for copper. Concentrations at the same depth are in the same range, except at the deepest depths, where the concentrations measured in the water sampled by the PUMP are three times higher. Concerning these four metals, the comparisons show similar range of concentrations between the two devices for each depth sampled, with the exception of random errors in several cases (Fig. 5).

\subsection{2. $\mathrm{Mn}, \mathrm{Fe}, \mathrm{Co}$}

Dissolved manganese, iron and cobalt concentrations are very low in the oxygenated water body (Fig. 5). With decreasing oxygen concentrations, dissolved $\mathrm{Mn}, \mathrm{Fe}$ and Co concentrations increase exponentially. For Fe and Co, concentrations measured in seawater sampled from the PUMP-CTD-System are in the same range in the oxic water but are higher across the oxic-anoxic interface and towards the oxygen depleted water. At $100 \mathrm{~m}$ depth, Co concentrations measured in the water sampled from the PUMP-CTD-System are three times higher. Nevertheless, $\mathrm{Fe}$ concentrations measured in the water sampled from the PUMP-CTD-System are lower than the seawater concentrations sampled from the CTD-Bottle-Rosette for the two deepest stations. Manganese concentrations are in the same range from both systems used, with higher difference between the two devices in the anoxic part.

\subsection{3. $\mathrm{Ni}$}

Dissolved $\mathrm{Ni}$ concentrations have similar distributions over the water column (Fig. 5). The profiles do not show any patterns at the interface or in the anoxic water. Despite of large standard deviations, concentrations measured in seawater from both devices and for each depth are in the same range.

\subsection{Comparisons of concentrations}

To investigate the difference in concentrations measured using either sampling systems in more detail, the percentage of concentration from the PUMP-CTD-System compared to the concentration from CTD-Bottle-Rosette for each depth, and averaged over the water column has been calculated for each element (Table 1). The calculation was based on the following equation:

\section{ð1/2PUMPSystem] — 1/2CTDbottles]m 100P=1/2CTD bottles]:}

Concerning the separated profiles, the concentrations measured from the PUMP-CTD-System are mostly higher, especially in the anoxic water body. These differences are largely supported by the time leg between the two profiles and the sampling itself. In fact, the PUMP profile was carried out $12 \mathrm{~h}$ after the CTD-Bottles-Rosette profile, which induces different water sampled, and so different depths and concentrations distributions $(\mathrm{Pb}, \mathrm{Cu}, \mathrm{Co}, \mathrm{Zn})$. The 
$\mathrm{T}\left({ }^{\circ} \mathrm{C}\right)$, salinity, $\mathrm{O}_{2}, \mathrm{H}_{2} \mathrm{~S}[\mathrm{ml} / \mathrm{l}]$
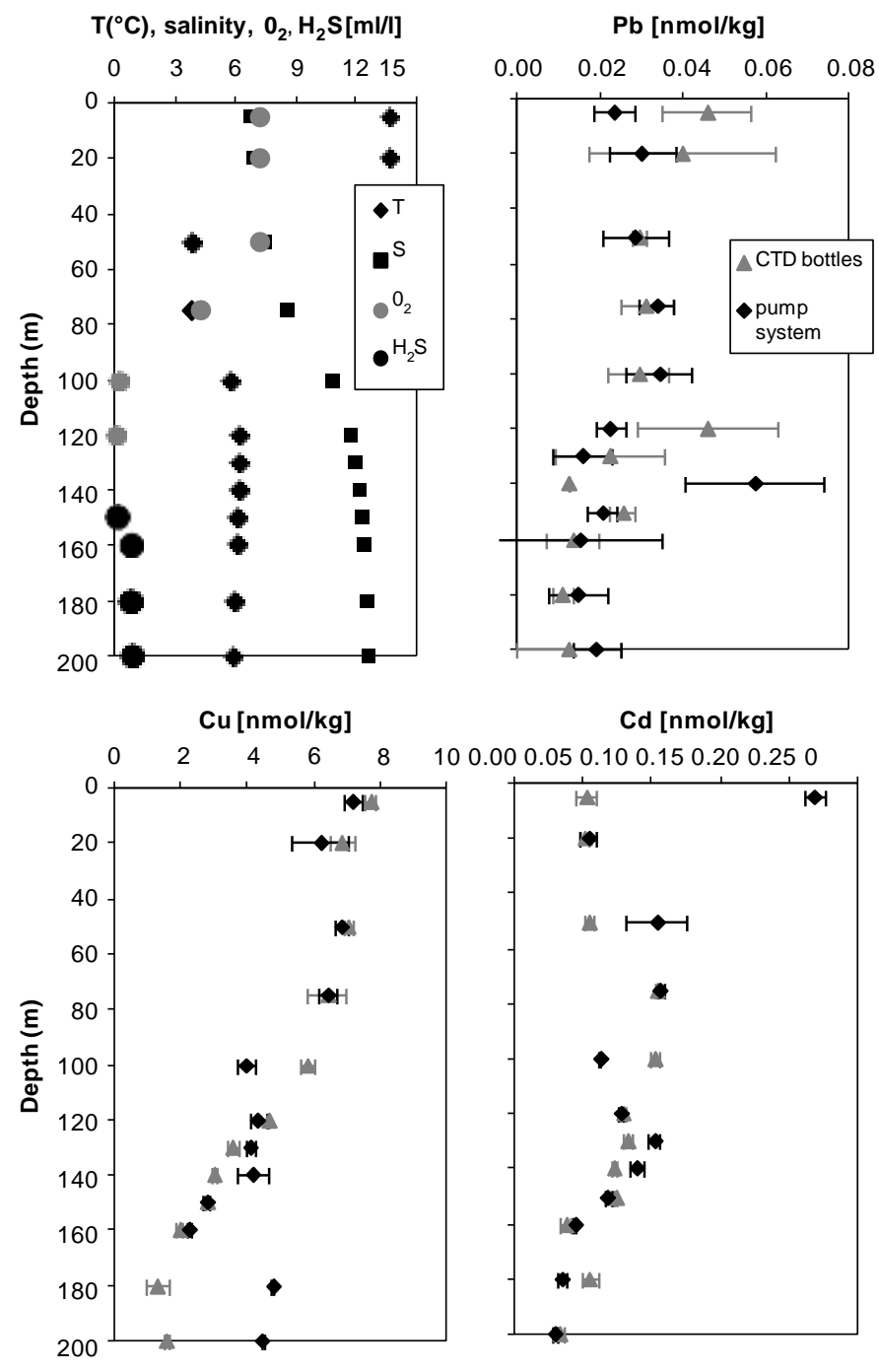

$\mathrm{Mn}[\mathrm{nmol} / \mathrm{kg}]$

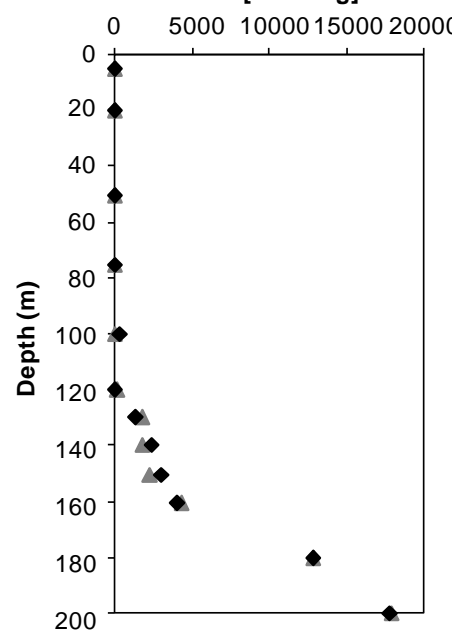

$\mathrm{Cd}[\mathrm{nmol} / \mathrm{kg}]$

100.000 .050 .100 .150 .200 .250

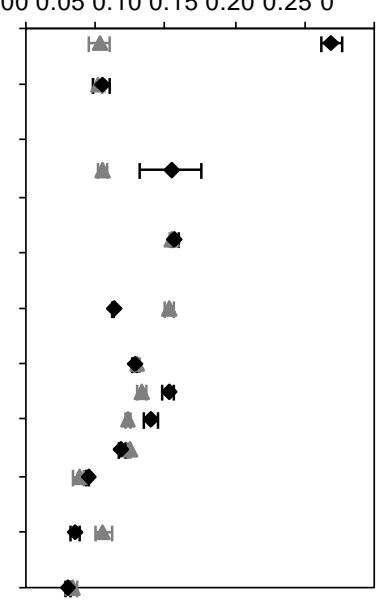

$\mathrm{Fe}[\mathrm{nmol} / \mathrm{kg}]$

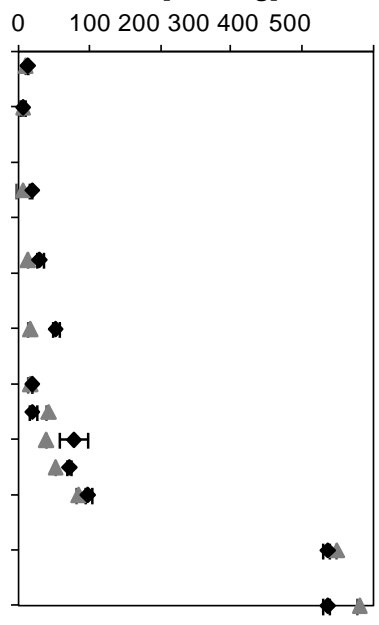

$\mathrm{Zn}[\mathrm{nmol} / \mathrm{kg}]$
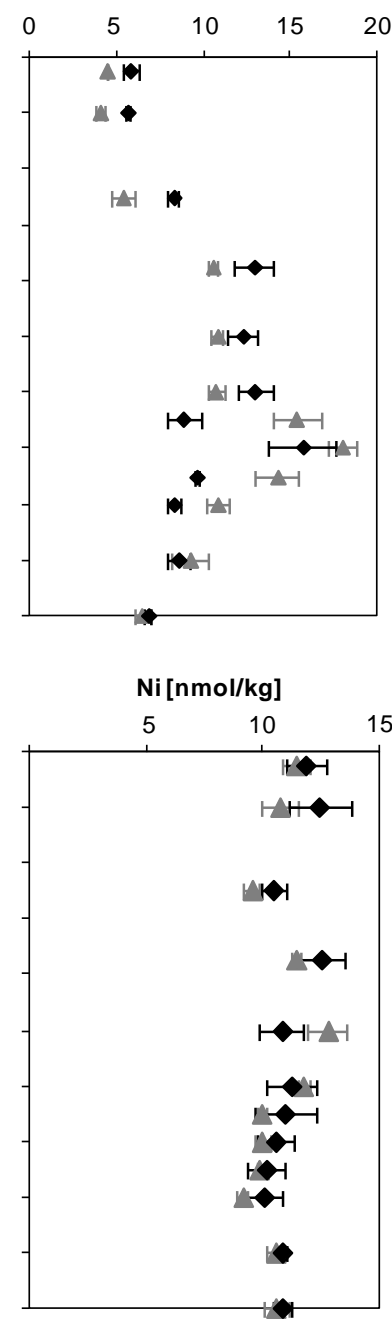

Co $[\mathrm{nmol} / \mathrm{kg}]$

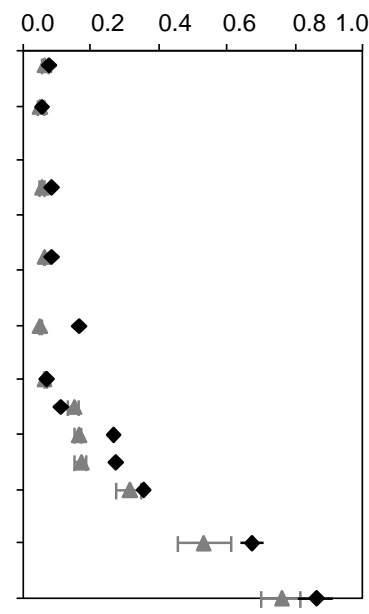

Fig. 5. Combined profiles, surface to bottom from October 2005: (a) profile of $T$ (temperature, ${ }^{\circ} \mathrm{C}$ ), $S$ (salinity), dissolved oxygen and hydrogen sulphide (ml/l) over depth and (b)-(i) profiles of dissolved $\mathrm{Pb}, \mathrm{Zn}, \mathrm{Cu}, \mathrm{Cd}, \mathrm{Ni}, \mathrm{Mn}, \mathrm{Fe}$ and $\mathrm{Co}$ (nmol/kg) sampled from the CTD-Bottle-Rosette and the PumpCTD-System over depth.

way of sampling is also relevant to investigate the different profiles of $\mathrm{Fe}$ and $\mathrm{Mn}$. It was carried out from the bottom to the surface, i.e. from the higher dissolved concentrations to the lower dissolved concentrations. These high 
Table 1

Concentrations comparison in \%: Pump-CTD-System to CTD-Bottle-Rosette

\begin{tabular}{|c|c|c|c|c|c|c|c|c|}
\hline$\%$ & $\mathrm{~Pb}$ & $\mathrm{Cd}$ & $\mathrm{Cu}$ & $\mathrm{Zn}$ & Co & $\mathrm{Fe}$ & $\mathrm{Ni}$ & $\mathrm{Mn}$ \\
\hline $\begin{array}{l}\text { Separated profile } \\
\text { Bottom to surface }\end{array}$ & 56.6 & -36.3 & 69.8 & 3.5 & 50.4 & 104.2 & 35.5 & 22 \\
\hline Combined profile & 26.2 & $-0.1^{\underline{\mathrm{a}}}$ & $0^{\underline{a}}$ & 17.9 & $14.5^{\mathrm{a}}$ & 18.8 & -2.9 & 5 a \\
\hline Surface to bottom & & $40^{\underline{b}}$ & $27.7^{\mathrm{b}}$ & & $30.6^{\underline{b}}$ & & & $61^{\underline{b}}$ \\
\hline
\end{tabular}

Positive values: concentrations measured using the pump are on average higher than using the CTD bottles. Negative values: concentrations measured using the pump are on average lower.

a Values excluded random contaminated samples.

b Values included random contaminated samples.

Table 2

Assigned precision (\%) of Reference Water (NASS-5 and CASS-3 for Mn only) given by the National Research Council, Canada, and measured in the laboratory between 2002 and $2006(n=18)$ in relation to calculated precision during sampling in October using the concentrations from both systems

\begin{tabular}{|c|c|c|c|c|}
\hline Precision $(\%)$ & $\mathrm{Pb}$ & $\mathrm{Cd}$ & $\mathrm{Cu}$ & $\mathrm{Zn}$ \\
\hline NASS-5 assigned (ng/l) & $8 \pm 5$ & $23 \pm 3$ & $297 \pm 46$ & $102 \pm 39$ \\
\hline Mean 2002-2006 & $7.14 \pm 3.7$ & $19.68 \pm 1.5$ & $298.85 \pm 42.0$ & $132.7 \pm 61.0$ \\
\hline Reference Water Laboratory long trend 2002-2006 $N=18$ & 51.3 & 7.8 & 14.0 & 56.8 \\
\hline Combined profile & 55.3 & $\begin{array}{l}20.9 \\
\text { a1 } 12.7\end{array}$ & $\begin{array}{l}19.4 \\
\text { a } 12.6\end{array}$ & 20.1 \\
\hline Precision $(\%)$ & Co & $\mathrm{Fe}$ & $\mathrm{Ni}$ & $\mathrm{Mn}$ \\
\hline NASS-5 water (ng/1) & $11 \pm 3$ & $207 \pm 35$ & $253 \pm 28$ & $2510 \pm 360$ \\
\hline Mean 2002-2006 & $10.76 \pm 1.6$ & $213 \pm 26.5$ & $248.19 \pm 14.7$ & $2691 \pm 229$ \\
\hline Reference Water Laboratory long trend 2002-2006 N = 18 & 15.0 & 13 & 5.9 & 8.5 \\
\hline Combined profile & 22.7 & 28.3 & 14 & 15.9 \\
\hline
\end{tabular}

${ }^{a}$ For $\mathrm{Cd}$ and $\mathrm{Cu}$, precision with low level contaminated samples excluded are also given.

concentrations (more than $18000 \mathrm{nmol} / \mathrm{kg}$ and $450 \mathrm{nmol} / \mathrm{kg}$, respectively for $\mathrm{Mn}$ and $\mathrm{Fe}$ ), could have lead to a low level contamination of the cable and the hose, and act as a "memory effect" visible in the next samples. This "memory effect" can not be proven, but can be avoiding by more flushing. The cadmium concentration comparison shows a different pattern with higher concentrations from the CTD-Bottle-Rosette. This can be attributed to a low level contamination with the use of the bottles, but can not also be proven.

Concerning the combined profile, the differences of concentrations between the two sampling devices are less pronounced For $\mathrm{Pb}, \mathrm{Cd}, \mathrm{Cu}, \mathrm{Co}, \mathrm{Zn}, \mathrm{Fe}$ and $\mathrm{Mn}$, the PUMPCTD-System yielded higher concentrations on average. Excluding contaminated samples, $\mathrm{Cd}, \mathrm{Cu}$, and $\mathrm{Mn}$ concentrations in seawater collected from both systems agree reasonably well. Contaminations were found at $5 \mathrm{~m}$ and $50 \mathrm{~m}$ depth for $\mathrm{Cd}$, at $180 \mathrm{~m}$ and $200 \mathrm{~m}$ for $\mathrm{Cu}$, and at $100 \mathrm{~m}$ for $\mathrm{Co}$ and $\mathrm{Mn}$. The comparison for $\mathrm{Ni}$ shows generally the same measured concentration for samples from the PUMP-CTD-System and the CTD-Bottle-Rosette.

\section{Discussion}

\subsection{Determination of the way of sampling}

The concentration differences between the two separate profiles sampled in July are possible due to the $12 \mathrm{~h}$ time lag between the two casts. Patchiness in the vertical distribution of several ingredients is common in that area under investigation. But the valuable information we got from that study was, that the trace metal concentration range of the waterbody was met by using two independent sampling systems. This was the catalyst for us to build an integrated system together with PUMP-CTD and Niskin bottles. In the Gotland Deep area, higher concentrations of redox-sensitive metals ( $\mathrm{Mn}$ and $\mathrm{Fe}$ ) in the anoxic water body lead us to perform sampling with the PUMP-CTDsystem from lower (surface) to higher (bottom) concentrations. If the element studied exhibit a peak at the redoxcline for example, we advise sampling at constant depth and flushing for a few minutes to avoid any memory effect on the hose.

\subsection{Potential factors contributing to the difference of concentrations between the two devices}

Detecting differences in trace metal concentrations across redox gradients with the use of GF-AAS is possible in the Baltic Sea system (Pohl et al., 2004, 2006; Pohl and Hennings, 2005), and also in Eastern Atlantic surface water (Pohl et al., 1993, 2007). Moreover, as this study point out the concentration changes and not only the absolute concentration values, the potential factors contributing to the differences of concentration between the two devices can be discussed. 
- First of all, the stainless steel PUMP inlet could be a possible source of contamination and lead to different trace metal concentrations in the water collected from the two devices. Then, other factors (more arbitrary), could have influence the difference of concentrations and so have to be taken into account.

- Due to physical processes (e.g. vertical and lateral fluxes, turbulence, mixing) and existing gradients, the concentrations of metals are never rigorously uniform in the water column. Thus two water samples taken with a few seconds or centimetres intervals represent different concentrations.

- In addition, the two sampling devices are different. With the CTD-bottles, the sampled water was flowing in from both sides of the bottle, which corresponds to a sampling integration over $1 \mathrm{~m}$ depth (height of the bottle). With the PUMP-CTD-System, the water was pumped through the PUMP inlet, just integrating over a distance of only few centimetres.

- The handling and the pre-treatment on board could also contribute to differences in concentrations between the systems, especially according to the quality and cleanliness of the acid, filters, filtration apparatus, LDPE bottles and the storage itself.

- Finally the analyses in the laboratory, and especially the analyst himself contributed to these differences. To resume, the comparison of the two devices appears difficult and not always accessible. Nevertheless, the precision of analyses in the laboratory can be estimated via the quality assurance.

\subsection{Quality assurance}

Laboratory analyses were ensured using two certified reference standard waters, NASS-5 (North Atlantic Seawater Standard) and CASS-3 (Coastal Atlantic Seawater Standard) from the National Research Council Canada. The data presented in Table 2 include the analyses since 2002. To compare the two devices, we looked if the difference of concentrations between the two devices were included or not in the analyses precision, given by the quality assurance. In this way, standard deviations of concentrations for both devices have been calculated for each element and each depth and have been averaged over the water column for each element and converted to precision (Table 2). The assumption made is that:

- If the precision calculated is lower than the precision for the CRM, the difference of the concentrations between the two systems is included in the measurement precision. In this case, the PUMP system is suitable to sample water for the determination of the respectable metal.

- If the precision calculated is higher than the precision of the CRM, the difference of the concentrations between the two systems is influenced by other processes.
For $\mathrm{Zn}$, the calculated precision value is lower than these of the CRM. Thus, differences of measured $\mathrm{Zn}$ concentrations, sampled with both devices over the water column, were within the measurement precision. For $\mathrm{Pb}$ and $\mathrm{Co}$, the precisions calculated are ranging between the precision of the CRM and measured in the laboratory since 2002. The precision calculated for this present study including the factors discussed in Section $\underline{4.2}$, and the difference between the precisions being low, we conclude that the PUMP-CTD-System is therefore well adapted to sample dissolved $\mathrm{Pb}, \mathrm{Zn}$ and $\mathrm{Co}$ through the water column and the redoxcline.

For $\mathrm{Cd}$ and $\mathrm{Cu}$, precision values calculated are slightly higher than the precision of the CRM. Nevertheless, if the low level contaminated samples are excluded in the calculation (at $5 \mathrm{~m}$ and $50 \mathrm{~m}$ depth for $\mathrm{Cd}$, and at $180 \mathrm{~m}$ and $200 \mathrm{~m}$ depth for $\mathrm{Cu}$ ), the calculated precisions values become lower than precisions of the CRM. For $\mathrm{Cd}$, this precision is still higher than the one achieved in the laboratory since 2002. But according to the other factors which could have contributed to this difference in concentrations and which were not taken into account in the quality assurance precision, we assume that dissolved $\mathrm{Cd}$ and $\mathrm{Cu}$ can be studied in the water column and through the redoxcline by using the PUMP-CTD-System. For Ni, the precision value calculated is also higher than of the CRM. As Ni concentrations does not exhibit changes at redoxcline, we assumed either a lack of measurements precision of the GFAAS method or either a low level contamination of the PUMPinlet made of stainless steel. For $\mathrm{Mn}$ and $\mathrm{Fe}$, the precision value calculated are higher than the precision value of the CRM. Therefore, the difference between the two devices (Table 2) is not only due to the precision of the measurement but possibly other processes as described below are contributing to the uncertainty.

\subsection{High vertical resolution profiles of dissolved oxygen concentrations}

Dissolved oxygen concentrations measured in suboxic and anoxic waters are differing between the used sampling systems (Fig. 6). Concentrations in seawater sampled by the PUMP-CTD-System were lower than in water sampled with the CTD-bottles. The resolution of the water inlet, 1 $\mathrm{m}$ with the bottles and a few $\mathrm{cm}$ with the PUMP, could contribute to the different concentrations. Nevertheless, we assume that the discrepancies are mainly caused by the sample handling onboard itself. In fact, to pour the water from the Niskin bottles, the upper cork of the bottle was unscrewed, and the water was in contact with atmospheric oxygen concentrations until the reagents were added and the water conserved in glass bottles. With the PUMP-CTD-System, the water flowed directly in the laboratory through a hose, and was immediately filled in a glass recipient, where the reagents were added. This procedure was considerably faster and allowed for only for a 


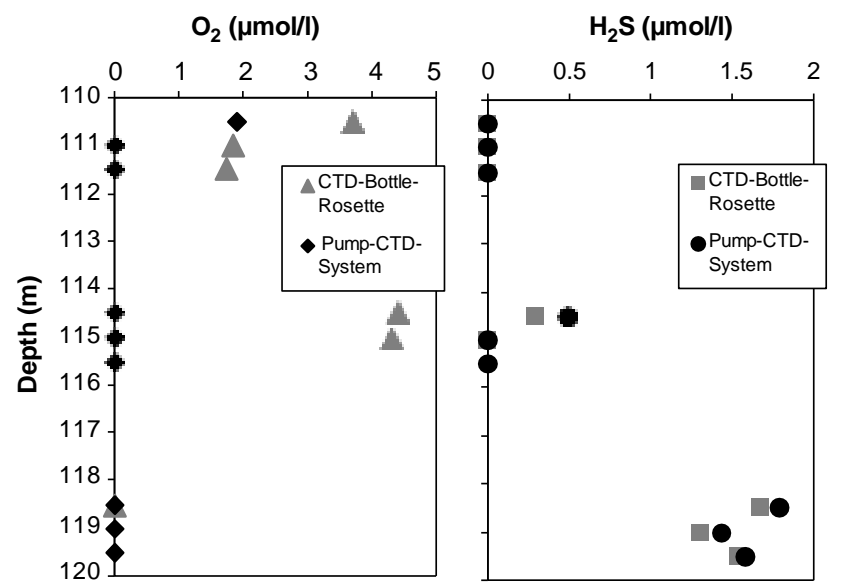

Fig. 6. Profiles of dissolved oxygen and hydrogen sulphide concentrations across the oxic-anoxic interface in Baltic Seawater (Gotland Basin) over depth, sampled with Pump-System and CTD bottles in February 2006.

very short contact time of the water with the atmospheric oxygen concentrations. Comparison of hydrogen sulphide distributions showed higher concentrations during sampling with the PUMP-CTD-System than with the CTDrosette. This may also be influenced by atmospheric oxygen diffusing into the water during the tapping of the water. An increased oxygen concentration in the water may induce the decrease of hydrogen sulphide formation.

To access oxygen and hydrogen sulphide concentrations closer to "in situ" concentrations and on a highervertical resolution, it is important to investigate the influence of the oxic-suboxic-anoxic gradient zone on metal speciation (Stunzhas and Yakushev, 2006). The oxidation state of iron and manganese at the redoxcline in the Baltic Sea (Kremling, 1983; Neretin et al., 2003) or in the Black Sea (Lewis and Landing, 1991; Murray et al., 1995) will be accessible and could provide precious observations to improve modelling (Oguz et al., 2001; Konovalov et al., 2004). Therefore, the quality and the precision of the sampling are increased with the PUMP-CTD-System.

\section{Conclusion}

The PUMP-CTD-System offers a new way for sampling interfaces of vertical structures in the water column The high vertical resolution, $1 \mathrm{~m}$ maximum, the CTD sensors, the adjustable water volumes sampled and the flow of water directly to the laboratory are particularly well adapted to study the oxic-anoxic interface in the Baltic Sea. Sampling dissolved trace metals with this system requires a sampling from the lower concentrations to the higher concentrations, which is generally from the surface to the bottom for water with anoxic conditions.

The potential re-oxidation of the water during onboard handling in the bottles could have induced the oxidation of dissolved $\mathrm{Mn}(\mathrm{II})$ and $\mathrm{Fe}(\mathrm{II})$ to insoluble $\mathrm{Mn}(\mathrm{IV})$ and $\mathrm{Fe}(\mathrm{III})$ and lead to the observed different concentrations between the two devices.
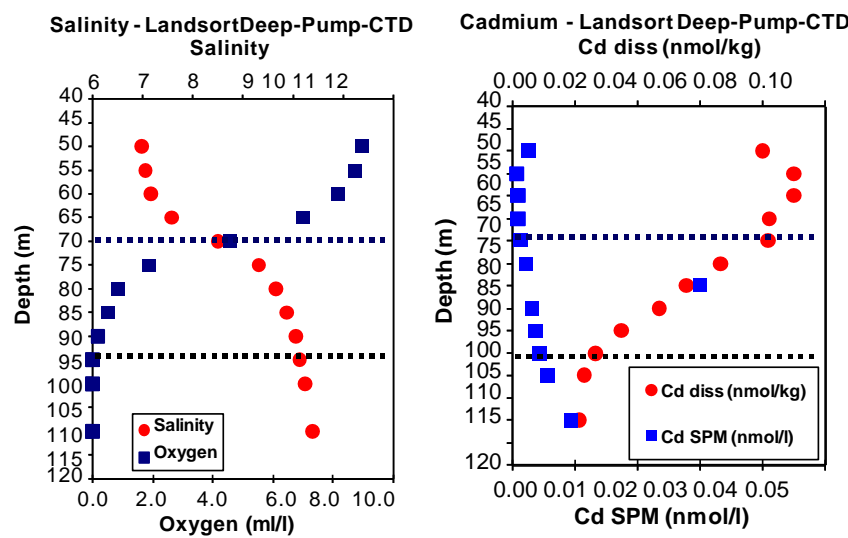

Fig. 7. Salinity, Oxygen, Cadmium in the dissolved (Cddiss) and in the particulate (CdSPM) fraction across the halocline at $\sim 70 \mathrm{~m}$ depth and the redoxcline at $\sim 95 \mathrm{~m}$ depth at station IOW 284 in the Landsort Deep, Baltic Sea.

To conclude, the IOW/MPI-PUMP-CTD-System can be used for studying dissolved $\mathrm{Pb}, \mathrm{Cd}, \mathrm{Cu}, \mathrm{Zn}, \mathrm{Fe}, \mathrm{Co}$, $\mathrm{Mn}$ and $\mathrm{Ni}$ in the water column. No major contaminations were detected, and the concentrations measured were close to the concentrations measured using the CTD-Bottle-Rosette. However, based on the results of this study, the stainless steel of the PUMP inlet has been substituted with ceramics to prevent contamination and a camera has also been attached, to avoid bottom contact. Thus, in future research, comparative studies of the two systems, will provide better observations and understanding of the small scale distributions and processes at the redoxcline. Spatial and temporal evolution like vertical, lateral fluxes and gradients will be accessible with the high resolution of the system. An example of a vertical profile with a resolution of $5 \mathrm{~m}$ across the halocline and the redoxcline in the Landsort Deep, (Maria S. Merian, March 2006) considering salinity, oxygen, and cadmium in the dissolved and particulate fraction is provided in Fig. 7.

However, sampling with the PUMP-CTD-system is not limited to the Baltic Sea. This device is suitable for coastal areas, semi-enclosed or closed seas, fjords and lakes, which are characterised by strong physical and biogeochemical interfaces. To optimise the technical performance of the system, we advise to adapt the way of sampling and the flushing to the distribution and concentrations of metal in the water column.

\section{Acknowledgements}

The authors are grateful to the captain and the crew of " $R V$ Professor Albrecht Penck" and " $R V$ Alkor", for their support during the expedition, and to Dr. G. Nausch for providing data for hydrogen sulphide and oxygen. We also thank gratefully the reviewers for their com- ments and their contribution to the improvement of the paper. 


\section{References}

Brezonik, P.L., Mach, C.E., Sampson, C.J., 2003. Geochemical controls for $\mathrm{Al}, \mathrm{Fe}, \mathrm{Mn}, \mathrm{Cd}, \mathrm{Cu}, \mathrm{Pb}$, and in during experimental acidification and recovery of Little Rock Lake, WI, USA. Biogeochemistry 62, 119-143. Bü gmann, L., 1974. Die Bestimmung von Spurenelementen im Meerwasser unter Verwendung einer stationa"ren Quecksilberelektrode. Acta Hydrochim. Hydrobiol. 2, 123-138.

Bru" gmann, L., 1988. Some peculiarities of the trace metal distribution in Baltic waters and sediments. Mar. Chem. 23, 425-440.

Danielsson, L.G., Magnusson, B., Westerlund, S., 1978. An improved metal extraction procedure for the determination of trace metals in sea water by atomic absorption spectrometrie with electrothermal atomisation. Anal. Chim. Acta 98, 47-57.

Friedrich, G.E., Codispoti, L.A., Sakamoto, C.M., 1988. Bottle and pumpcast Data from the 1988 Black Sea Expedition, MBARI, Technical Report No. 90-3. Pacific Grove, Monterey, CA 93950, USA. Grasshoff, K., Kremling, K., Ehrhardt, M., 1999. Methods of Seawater Analyses, third ed. Wiley-VCH Verlag GmbH, Weinheim, Germany, p. 600.

Konovalov, S., Samodurov, A., Oguz, T., Ivanov, L., 2004. Parameterization of iron and manganese cycling in the Black Sea suboxic and anoxic environment. Deep Sea Res. I 51, 2027-2045.

Kremling, K., 1973. Voltammetrische Messungen ü ber die Verteilung von Zink, Cadmium, Blei und Kupfer in der Ostsee. Kieler Meeresforsch. 29 (2), 77-84.

Kremling, K., 1983. The behaviour of $\mathrm{Zn}, \mathrm{Cd}, \mathrm{Cu}, \mathrm{Ni}, \mathrm{Co}, \mathrm{Fe}$, and $\mathrm{Mn}$ in anoxic Baltic waters. Mar. Chem. 13, 87-108.

Krueger, S., 2004. Operating Manual, Integrated IOW/MPI PUMP CTD System, IOW, Warnemuende Germany; <Siegfried.Krueger@iowarnemuende.de>.

Lewis, B.L., Landing, W.M., 1991. The biogeochemistry of manganese and iron in the Black Sea. Deep-Sea Res. 38 (Suppl. 2A), S773-S804.

Lo" scher, B.M., 1999. Relationships among Ni, Cu, $\mathrm{Zn}$ and major nutrients in the Southern Ocean. Mar. Chem. 67, 67-102.

Murray, J.W., Codispoti, L.A., Friederich, G.E., 1995. Oxidationreduction environments: the suboxic zone in the Black Sea. In: Huang, C.P., O’Melia, C., Morgan, J.J. (Eds.), Aquatic Chemistry: Interfacial and Interspecies Processes, . In: Adv. Chem. Ser., vol. 244. American Chemical Society, Washington DC, pp. 157-176.

Neretin, L.N., Pohl, C., Jost, G., Leipe, T., Pollehne, F., 2003. Manganese cycling in the Gotland Deep, Baltic Sea. Mar. Chem. 82, 125-143.

Oguz, T., Murray, J.W., Callahan, A., 2001. Modelling redox cycling across the suboxic-anoxic interface zone in the Black Sea. Deep-Sea Res. I 48, 761-787.
Patterson, C.C., Settle, D.M., 1976. The reduction of orders of magnitude errors in lead analyses of biological materials and natural waters by evaluating and controlling the extent and sources of industrial lead contamination introduced during sample collecting, handling, and analysis. Natl Bureau Stand. Special Publ. 422, 321-351.

Pohl, C., Hennings, U., 1999. The effect of redox processes on the partitioning of $\mathrm{Cd}, \mathrm{Pb}, \mathrm{Cu}$, and $\mathrm{Mn}$ between dissolved and particulate phases in the Baltic Sea. Mar. Chem. 65 (1-2), 41-53.

Pohl, C., Hennings, U., 2005. The coupling of long term trace metal trends to internal trace metal fluxes at the oxic-anoxic interface in the Gotland Basin $\left(57^{\circ} 19,20^{\prime} \mathrm{N} ; 2^{\circ} 03,00^{\prime} \mathrm{E}\right)$ Baltic Sea. J. Mar. Sys. 56, 207-225.

Pohl, C., Kattner, G., Schulz-Baldes, M., 1993. Cadmium, copper, lead and zinc on transects through Arctic and Eastern Atlantic surface and deep waters. J. Mar. Syst. 4, 17-29.

Pohl, C., Lo" ffler, A., Hennings, U., 2004. A sediment trap flux study for trace metals under seasonal aspects in the stratified Baltic Sea (Gotland Basin $\left.57^{\circ} 19,20^{\prime} \mathrm{N} ; 2^{\circ} 03,00^{\prime} \mathrm{E}\right)$. Mar. Chem. 84, 143-160.

Pohl, C., Lo" ffler, A., Schmidt, M., Seifert, T., 2006. A trace metal (Pb, Cd, $\mathrm{Zn}, \mathrm{Cu}$ ) balance for surface waters in the eastern Gotland Basin, Baltic Sea. J. Mar. Sys. 60, 381-395.

Pohl, C., Hennings, U., Rutgers v. d. Loeff, M., Croot, P., Budeus, G., 2007. Trace metal $(\mathrm{Hg}, \mathrm{Pb}, \mathrm{Cd}, \mathrm{Cu}, \mathrm{Ni}, \mathrm{Mn}, \mathrm{Fe}, \mathrm{Co})$ distribution in Eastern-Atlantic surface waters. Reflection of natural and anthropogenic sources by comparing data from 1990 and 2005. Geophysical Research Abstracts, vol. 9, A-01316, EGU-General Assembly, Vienna, Austria.

Rondeau, B., Cossa, D., Gagnon, P., Pham, T.T., Surette, C., 2005. Hydrological and biogeochemical dynamics of the minor and trace elements in the St. Lawrence River. Appl. Geochem. 20, 1391- 1408.

San udo-Wilhelmy, S.A., Olsen, K.A., Scelfo, J.M., Foster, T.D., Flegal, A.R., 2002. Trace metal distributions off the Antarctic peninsula in the Weddell sea. Mar. Chem. 77 (2-3), 157-170.

Schneider, B., Ceburnis, D., Marks, R., Munthe, J., Petersen, G., Sofiey, M., 2000. Atmospheric $\mathrm{Pb}$ and $\mathrm{Cd}$ input into the Baltic Sea: a new estimate based on measurements. Mar. Chem. 71, 297-307.

Stunzhas, P.A., Yakushev, E.V., 2006. Fine hydrochemical structure of the redox zone in the Black Sea according to the results of measurements with an open oxygen sensor and with bottle samplers. Oceanology 46 (5), 629-641.

Waeles, M., Risdo, R.D., Mahuer, J.F., Le Corre, P., 2004. Distribution and chemical speciation of dissolved cadmium and copper in the Loire estuary and North Biscay continental shelf, France. Estuar., Coast. Shelf Sci. 59, 49-57. 